\title{
'n Pastoraal hermeneutiese lees van Paulus se briewe: 1 Tessalonisense as toetsgeval
}

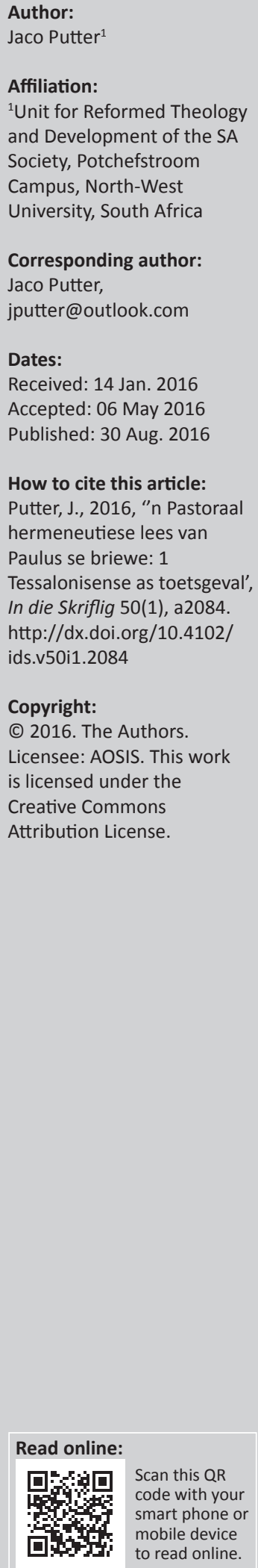

Paul's letters, filled with pastoral content, are illustrating how he founded the church communities, shaping them and caring for them with various techniques. Paul shaped these communities within their own contexts after they had received and accepted the gospel. The outcome was that such a church community and its individuals created their own worldview from which they viewed and experienced the world. It is argued here that their worldview influenced the individuals' and groups' identity, values, norms and actions. All these aspects influenced each other in an interactive dynamic way with interdependence as a result. If one aspect changes, it affects all the other areas. These aspects are rooted in the individual's emotive and cognitive areas. Paul addresses this in his letters by referring to these two areas on a constant basis by reflecting on how the converts had to change the way they thought and lived in order to imitate Christ. This motivated them to endure difficult situations they found themselves in. When reading Paul's letters with this in mind a new pastoral understanding of it emerges, as illustrated with reference to 1 Thessalonians.

\section{Inleiding}

In hierdie artikel word 'n model ontwikkel wat 'n lens bied vir die lees van 1 Tessalonisense. Dit word gedoen deur 1 Tessalonisense as toetsgeval te gebruik.

Dit is duidelik deur kundiges aangetoon dat 1 Tessalonisense pastorale elemente bevat en dus pastoraal van aard is (Malherbe 2000:92; Thompson 2006:34, 53; Thiselton 2011:10; Wanamaker 2000:255). Thompson (2006:31) toon aan dat Paulus deur middel van 'n pastorale visie die gemeenskap van Tessalonisense bedien het. Hy het byvoorbeeld vir Timoteus gestuur (1 Tess 3:2; Thompson 2006:31-32) wat vir Wanamaker (2000:255)'n aanduiding is dat Paulus met sy pastorale werk volhard het. Paulus het nie net vir hulle teologiese ontwikkeling omgegee nie, maar ook vir hulle emosionele en geestelike versorging (Witherington 2006:xvi). Die doel van hierdie artikel is nie om al die pastorale aktiwiteite in 1 Tessalonisense te beskryf nie, maar eerder om die teks van 1 Tessalonisense aan die model te koppel.

Om so 'n model te ontwikkel, vereis 'n interdissiplinêre ${ }^{1}$ studie tussen Nuwe-Testamentiese en sosiale wetenskappe. Verskeie kundiges se modelle word geïntegreer om 'n interaktiewe dinamiek voor te stel. Dit is belangrik om eerstens aandag te gee aan hermeneutiek waarna die sosiale benadering beskryf sal word.

\section{Hermeneutiek}

Die rol van hermeneutiek in hierdie artikel is om 'n verstaansraamwerk te vorm waarbinne die sosiologiese analise opereer. As deel van interdissiplinêre navorsing dink praktiese teoloë nie net aan 'n dialoog met die sosiale wetenskappe nie, maar ook aan 'n dialoog met teologiese dissiplines (Osmer 2012:72). Die uitdaging van hierdie artikel is om rekening te hou met die verskillende aksente wat op hermeneutiek geplaas word en veral hoe die tekste gelees word (Runia 1984:121). Hier word by Thiselton (2009:4) aangesluit wat'n onderskeid tref tussen eksegese en hermeneutiek. Thiselton (2009:4) verduidelik eksegese as die proses waarmee tekste geïnterpreteer word en hermeneutiek as die kritiese vrae wat gevra word oor wat gedoen word wanneer hierdie tekste gelees, verstaan of toegepas word. Volgens Thiselton (2009:4) ondersoek hermeneutiek die verskillende kriteria waarvolgens 'n teks gelees kan word. Hierdie kriteria word altyd deur die leser se eie wêreldbeeld en voorafkennis beïnvloed wat' $n$ uitwerking op sy of haar interpretasie van 'n gegewe teks het (Bowald 2007:367). Daar is altyd dan die spanning oor wie se interpretasie 1.Met interdissiplinêr word bedoel die gebruik van die Nuwe-Testamentiese wetenskap en die sosiale wetenskap met verwysing na
sekere antropologiese aspekte. Die rede vir die afbakening is die diverse betekenisse wat aan die term interdissiplinêr gegee word (Aagaard-Hansen 2007:425-426; Osmer 2012). 
aanvaar moet word en watter verklaring van die teks korrek is (Stamoolis 2004:338).

Lategan (2009a:14) is van mening dat hermeneutiek met die kuns van verstaan te make het. Dit stel uiteraard uitdagings aan die leser om die kuns van interpretasie delikaat uit te voer. Dit is daarom noodsaaklik om die regte hermeneutiese keuses uit te oefen wanneer tekste gelees word en eerlik te wees waarom hermeneutiese keuses gemaak word (Kahan 2010:138; Luckensmeyer 2009:10). Vir Luckensmeyer (2009:10) is dit belangrik dat interpreteerders hulle eie vooronderstellings in gesprek met die teks bring en dat hierdie vooronderstellings deur die teks gevorm word en nie andersom nie.

Indien dit nie gedoen word nie, kan dit gebeur dat die Bybel misbruik word, byvoorbeeld dat sommige interpreteerders betekenisse in die teks lees wat nie bestaan nie, of die Bybel reduseer tot sekere temas wat nie in die teks verskyn nie. Verder kan dit ook gebeur dat interpreteerders besluit die Bybel is irrelevant vir komplekse sake in die moderne lewe (Kahan 2010:138). Lategan (2009a:20) waarsku om nie hermeneutiek van buite op die Bybel af te forseer nie. Lategan (2009a:20) argumenteer dat bybelse hermeneutiek iets is wat vanuit die teks self ontwikkel en so respekteer moet word. Die klem word daarom nie op die leser en die leser se vermoëns geplaas om te interpreteer nie, maar eerder op die teks en die boodskap in die teks (Bowald 2007:381).

Lategan (2009a:59) is van mening dat bybelse hermeneutiek aanvaarbaar is indien besef word dat die Bybel die potensiaal het om self te kommunikeer en dat die leser van vandag nie die eerste leser van die teks is nie. Thiselton (2009:1) brei verder hierop uit en argumenteer dat hermeneutiek ook te make het met hoe die teks gelees, verstaan en hanteer word. Alhoewel dit na 'n simplistiese oefening klink, bly die probleem dat die Nuwe Testament ' $n$ boek is wat in ' $n$ ander tyd en konteks as die huidige geskryf is en dat moderne lesers verskillend op Bybeltekste reageer (Thiselton 2009:1). Thiselton (2009:1) dui aan dat hermeneutiek meer as een akademiese dissipline kan insluit, juis omdat dit bybelse vrae (wat met Bybeltekste verband hou) en teologiese vrae (wat met Christelike teologie verband hou) vra. Hermeneutiese vrae lei ook daartoe dat filosofiese vrae, literêre vrae, sosiale vrae, ensovoorts, gevra moet word om 'n teks beter te verstaan (Thiselton 2009:1). Volgens Hays (2006:3-4) is dit noodsaaklik om die hermeneutiese vrae te struktureer en dit makliker te maak vir die interpreteerder om homself te posisioneer. Dit dui aan waar die interpreteerder is en waarop die teks mik (Lategan 2009b:66).

Hays (2006:15-16) stel 'n model voor wat hy 'n Metaphorical embodiment of narrative paradigms noem wat handel oor die narratiewe in die Bybel wat God se verlossingswerk beskryf en wat 'n simboliese wêreld skep waar die mens identiteit en oriëntasie kan vind. In hierdie model is dit belangrik dat die eksegeet in gedagte moet hou dat die teks beliggaam moet word. In Hays (2006) se woorde:
The text shapes the community, and the community embodies the meaning of the text. Thus there is a hermeneutical feedback loop that generates fresh readings of the New Testament as the community grows in maturity and as it confronts changing situations. (p. 16)

Volgens Hays (2006:18) is die belangrikste hermeneutiese taak om gemeenskappe deur die kommunikasie van die bybelse narratief te vorm wat hulle volgens Bybelse beginsels laat leef.

\section{'n Sosiale benadering}

Hays (2006:15-16) se benadering word as sleutel gebruik om ondersoek in te stel hoe Paulus se prediking die gemeente in Tessalonika gehelp het om die evangelie te beliggaam in hulle eie konteks. So word die simboliese wêreld wat Paulus geskep het deur sy prediking sowel as die identiteit, oriëntasie en disoriëntasie van die nuwe bekeerlinge in 1 Tessalonisense ondersoek. Malherbe (1987:vii) toon aan dat dit belangrik is om 1 Tessalonisense te lees vanuit die kultuur waarin die gemeenskap en Paulus geleef het. Dit vra na 'n sosiale lees van die brief. Witherington (2006:xv) ondersteun die gedagte en argumenteer dat die situasie tydens en na Paulus se besoek belangrik is vir so 'n ondersoek. Volgens Malherbe (2000:13) is Paulus se prediking rigtinggewend vir so 'n ondersoek ten einde sy simboliese wêreld te verstaan. 'n Verdere aspek wat Malherbe (1989:2-9) uitlig, is die verband tussen Paulus en die filosofiese skole van sy tyd. Malherbe (1989:6-8) toon aan dat 'n deeglike uiteensetting van die ooreenkomste en verskille tussen Paulus en die verskillende filosofiese tegnieke en toepassings ' $n$ belangrike hermeneutiese sleutel is. Luckensmeyer (2009:11) ondersteun Malherbe, maar wys daarop dat die moderne leser onderskeid moet maak tussen die metodes wat Paulus gebruik het en metodes wat deur moderne teoloë van vandag gebruik word. Die metodes wat Paulus gebruik het, werp lig op hoe Paulus in sy tyd met sy prediking teologiese perspektiewe aan die nuwe bekeerlinge oorgedra het (Malherbe 2000:13). Dit impliseer dat 1 Tessalonisense gelees moet word vanuit die sosiale konteks waarin dit ontstaan het. Volgens Malherbe (1977:7-8) is die doel nie om bloot die historiese data te beskryf nie, maar eerder om Christengemeenskappe in sosiale kontekste te beskryf en die dinamiek daarvan te probeer peil. 'n Beskrywing van die gemeenskap help met die verstaan van die betekenis wat binne so 'n gemeenskap gekonstrueer word (Brown 1987:122).

Gemeenskappe gee dan uitdrukking aan hierdie betekenisse deur middel van taal wat die simboliese werklikheid van 'n gegewe gemeenskap kommunikeer (Berger \& Luckmann 1966:55). Dit maak interpretasie moeilik omdat die betekenis van woorde in die sosiale sisteem lê en nie noodwendig in woordeboeke nie (Neyrey 2008:xxi). Neyrey (2008:xxi) argumenteer dat ons maar bloot kan spekuleer wat woorde en betekenisse in die Grieks-Romeinse wêreld werklik sou beteken. Daarom waarsku Neyrey (2008:xxi) dat daar nie 'kortpaaie' geloop kan word met 'n sosiale lees van die Nuwe Testament nie, maar dat daar kennis geneem moet 
word dat hierdie woorde in 'n spesifieke kulturele sisteem met 'n spesifieke kulturele betekenis ingebed was. Rubin en Rubin (1995:20) toon aan dat betekenisse en realiteite nie in isolasie plaasvind nie, maar dat daar binne elke gemeenskap 'n gedeelde realiteit is. Berger en Luckmann (1966:114) definieer ' $\mathrm{n}$ simboliese universum as 'the matrix of all socially objectivated and subjectivively with special regard to "real meanings"'. Daar vind 'n dinamiese interaksie plaas tussen die individu en die gemeenskap wat in die realiteit van die simboliese universum geanker is. Die simboliese universum kan ook gesien word as 'n sambreel wat oor die alledaagse werklikheid van 'n samelewing oopgemaak word (Berger \& Luckmann 1966:120). 'n Simboliese universum bestaan uit samebindende faktore wat die werklikheid aanmekaar bind. Horrel (1993:93) is van mening dat hierdie faktore deeglik ondersoek moet word om vas te stel wat die samebindende faktore is wat ' $n$ instelling in stand hou. Daarom is dit nodig om vrae te vra wat verband hou met die simboliese universum van samelewings. Freedman en Combs (1996:22) sê dat realiteite sosiale konstruksies is, dat hierdie konstruksies deur taal gekonstrueer word, deur narratiewe georganiseer word in gemeenskappe en dat gemeenskappe wat realiteite skep geen absolute waarhede volg as daar realiteite geskep word nie. Wanneer ondersoek ingestel word na 'n simboliese universum is die vrae van Freedman en Combs (1996:40) baie nuttig:

- Benodig ons beskrywings vir meer as een realiteit?

- As ons realiteite wil verstaan, luister ons na al die rolspelers se taal?

- Gebruik ons die taal van die werklikheid van die persone waarna ons luister?

- Wat is die informasie wat gebruik word om die taal wat gebruik word te ondersteun?

Om hierdie rede word die sosiale benadering tot die vroeë Christendom gekies wat die vroeë Christendom en hulle literatuur ernstig opneem (Malherbe 1977:11). Dit is waarom die sosiale faktore wat bygedra het tot die ontwikkeling van so 'n gemeenskap van onskatbare waarde is (Malherbe 1977:11).

\section{Bestaande modelle}

Om die evangelie aan die Tessalonisense te verkondig, moes Paulus 'n spesifieke boodskap of simboliese universum aan hulle kommunikeer. Hy moes ook in voeling wees met hulle kognitiewe en emotiewe prosesse en omstandighede. Hierdie proses is deur Paulus se persoonlike betrokkenheid by hulle geaktiveer en dan veral deur die verkondiging van die evangelie.

Die modelle van Engberg-Pedersen (2000), Hiebert (2008) en Van der Watt (2010) word bespreek en 'n geïntegreerde hermeneutiese model word voorgestel om die simboliese universum van Paulus in 1 Tessalonisense te interpreteer. Die model van Engberg-Pedersen (2000:34-36) toon aan hoe 'n individu 'n simboliese universum betree. Hiebert (2008) en Van derWatt (2010) se modelle toon aan hoe individue'n wêreldbeeld vorm, kognitief en emotief ervaar en in stand hou.
Engberg-Pedersen (2000:34) argumenteer dat Paulus gebruik gemaak het van ' $n$ 'map of reading ${ }^{2}$ toe hy die Tessalonisense blootgestel het aan die simboliese universum binne hulle sosiale omstandighede. Die map of reading waarvan Paulus gebruik maak, hou moontlik verband met die basiese raamwerk om geloofsverbintenisse te verstaan (Walsh \& Middleton 1984:35). Die oriëntasie van die individu is belangrik in terme van die aard van die wêreld of universum waarin die individu leef (Walsh \& Middleton 1984:35). Walsh en Middleton (1984:35) suggereer dat die simboliese universum gefundeer is in geloof. Volgens Walsh en Middleton (1984:35) vorm mense 'n wêreldbeeld op grond van hulle geloofsverbintenis wat gegrond is op die volgende vrae: Wie is ek?; Waar is ek?; Wat is fout?; en Wat is die oplossing? Dit kan in eenvoudiger terme verstaan word as bekering soos wat die gemeente van Tessalonika in Tessalonisense 1:9 hulle van die afgode tot die lewende God bekeer het.

Die hele kaart ('map of reading') wat Engberg-Pedersen (2000:34) $)^{3}$ voorstel, beskryf die proses hoe 'n individu se identiteit verander nadat hy of sy begin om met God te identifiseer. Hierdie verandering hou verband met persepsies en ook met verhoudings in 'n gemeenskap. Die model is normatief in die opsig dat dit illustreer hoe 'n individu se denkraamwerk skuif van 'ek'-denke na 'ons'-denke (EngbergPedersen 2000:34-35). Indien die kaart gelees word, word daar'n bo- en onderkant beskryf. Die bokant word as positief beskryf en die onderkant as negatief. Daar word op 'n liniêre lyn 'n verlede, 'n hede en 'n toekoms beskryf. Aan die onderkant en by die verlede staan die 'ek' (I) wat selfgerig is en wat gedryf word deur selfgerigte denke. EngbergPedersen (2000:34-35) illustreer verder dat die bokant, die hede en die toekoms as positief beskou kan word sowel as die posisies op die kaart waar die individu positief verander het. Die rede hiervoor is dat die individu deur 'iets' aangeraak is en op die kaart verwys dit na God (X). Engberg-Pedersen (2000:34-35) toon verder aan dat die individu verander na 'n 'ons'-identiteit wat positief is, omdat dit deur God bepaal word deur Christus (S) wat persone se lewens aanraak. Volgens Engberg-Pedersen (2000:35) toon dit aan dat die individu se vorige negatiewe toestand verander is na ' $n$ nuwe positiewe toestand. Die ' $\mathrm{ek}^{\prime}$ en God word aan mekaar verbind met 'n lyn wat in twee rigtings kan beweeg. Dit dui op 'n dinamiese model waar groei kan plaasvind. 'An earlier, bad state of an individual is exchanged for a new and good one' (Engberg-Pedersen 2000:35). Die oomblik as die individu met God begin identifiseer, begin hy of sy die evangelie beliggaam. Dit is onmoontlik vir enige individu om onmiddellik of permanent vry te kom van die 'ek'identiteit en daarom moet die individu voortdurend herinner word aan die nuwe identiteit in God deur die Christusgebeure. Hierdie is 'n konstante proses wat sigbaar is in 1 Tessalonisense (1:3; $1: 10 ; 3: 13 ; 4: 16-17)$. Dit is duidelik in die kaart van Engberg-Pedersen (2000:34-36) dat daar 'n skuif in die 2.Sien Figuur 1.

3. Hierdie is dieselfde proses wat bekend was aan die Stoïsyne. Raadpleeg EngbergPederson (2000:34) in hierdie verband. 


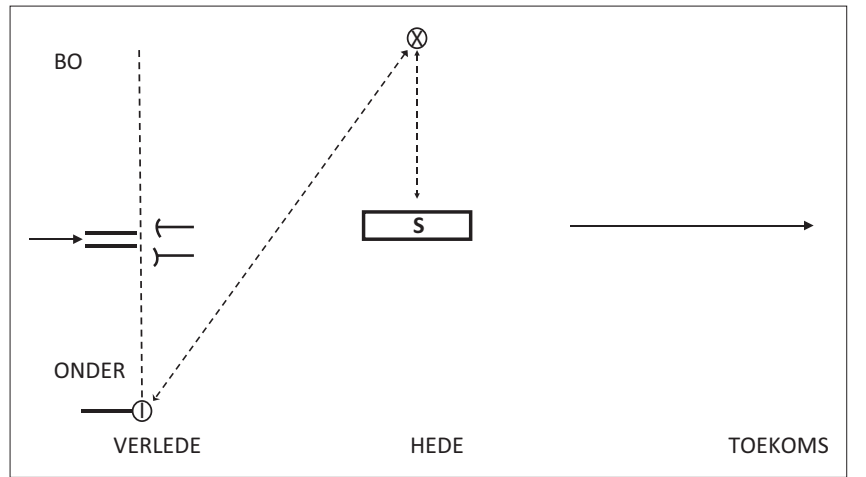

Bron: Engberg-Pedersen, T., 2000, Paul and the stoics, T\&T Clark Ltd., Edinburgh

FIGUUR 1: Verandering van 'ek' identiteit na 'ons' identiteit.

persepsie van die individu plaasgevind het. Dit vind aansluiting by die gedagte dat die simboliese universum van persone skuif en dat nuwe betekenisse aan persone se lewe geheg word as persepsies verander. Dit word as volg skematies voorgestel (sien figuur 1).

In die skematiese uiteensetting word duidelik aangetoon dat die individu deur 'n spesifieke proses gaan om in 'n nuwe simboliese universum 'opgeneem' te word. So 'n persoon se lewe word in die nuwe wêreld geïntegreer. Dit beteken dat die individu hom- of haarself al meer begin sien as die eiendom van God $(X)$. Die pyltjie wat af wys van $X$ na $S$ verwys terug na die verhouding tussen God en die individu wat ten doel gehad het om die individu by Christus uit te bring (Engberg-Pedersen 2000:35). Die pyltjie wat van die S na die $X$ wys, verwys na die motief om die individu te bevry van die 'ek' identiteit'.

Hierdie proses aktiveer nuwe kognitiewe en emotiewe prosesse en die individu begin hom- of haarself al meer losmaak van die ou simboliese universum van die 'ek'. In 1 Tessalonisense het die gemeente reeds tot bekering gekom, maar Paulus herinner hulle aan hulle eie proses van bekering sodat hulle kan weet dat hulle nie meer die ou lewe leef nie, maar opgeneem is in die nuwe simboliese universum waar die lewende God hulle Here is en dat hulle moet onthou dat hulle wag op die koms van die Here Jesus Christus wat opgestaan het (1:9-10).

Van der Watt (2010:13) brei verder hierop uit en toon aan dat daar nou 'n verband bestaan tussen ' $n$ individu se wêreldbeeld en aksies. Sy model word deur 'n liniêre struktuur voorgestel wat 'n oorsig gee oor die proses hoe 'n wêreldbeeld die aksies van 'n persoon bepaal. Van der Watt (2010:14) beskryf 'n liniêre proses $^{4}$ waar die wêreldbeeld van 'n individu tot sy of haar identiteit lei en tot uitdrukking kom in die persoon se waardes en norme wat in voorgeskrewe aksies uitgeleef word. Dit is belangrik om die terme te omskryf vir 'n deeglike integrering met die ander modelle. Die terme wêreldbeeld, identiteit, waardes, norme en aksies is belangrike terme wat in die lees van 1 Tessalonisense na vore kom. Dit is egter nie moontlik om al die terme hier te beskryf nie. Ek beperk my dus tot enkeles.

4.Ek volg die beskrywing van die proses in Van der Watt (2010:14-27).
Die term wêreldbeeld ${ }^{5}$ is belangrike en kan baie wyd omskryf word. Dit is daarom belangrik om die term te begrens vir die doel van die artikel. 'n Wêreldbeeld word deur Van der Watt (2010:14) as 'organizing and relating the totality of objects in a person's personal universe' beskryf. Van der Watt (2010:15) beskryf die term wêreldbeeld duideliker deur daarna te verwys as die kognitiewe wêreld van 'n individu wat die totale ervaring van hulle werklikheid insluit. Baumann (2011:11) argumenteer dat 'n wêreldbeeld die hoofrede is vir die mens se oriëntasie en dat die teenoorgestelde ook waar is: daarsonder sou die mens gedisoriënteerd wees. Daarom is 'n wêreldbeeld van kardinale belang vir 'n gemeenskap om sekere realiteite van die lewe as betekenisvol te sien en te ervaar (Baumann 2011:11). Dit dien ook as 'n filter waardeur die gemeenskap na die wêreld kan kyk om sodoende sekere waardes en norme in hulle lewe te integreer (Baumann 2011:11; Walsh \& Midldeton 1984:32). Van der Watt (2010:14) bevestig dat mense se persepsies deel vorm van hulle ervaringswêreld en dat daar 'n direkte verband is met hulle gedrag. Hierdie ervaringswêreld word met mekaar gedeel as die kognitiewe en emotiewe ervarings van die wêreldbeeld dieselfde is (Baumann 2011:34; Hiebert 2008:26; Van der Watt 2010:15). ${ }^{6}$ Charon (2004:9) sê dat vooroordele en perspektiewe nie noodwendig gekies word nie, maar produkte is van die gemeenskap waarin mense leef. Die gevolgtrekking kan dus gemaak word dat 'n wêreldbeeld nie uitsluitlik aan 'n individu behoort nie, maar altyd gemeenskaplik ontwikkel waar meer as een persoon 'n gemeenskaplike visie en kultuur deel (Walsh \& Middleton 1984:32).

Die werk van Hiebert (2008) en Van der Watt (2010) het verskille en ooreenkomste. Dit kom ooreen in dié opsig dat daar' $n$ verband tussen die wêreldbeeld en die aksie of gedrag gelê kan word. Die verskil tussen die twee modelle hou verband met die liniêre (kognitiewe) model van Van der Watt (2010) en die meer kousaal-georiënteerde model van Hiebert (2008). Hiebert (2008:25-26) definieer wêreldbeeld as: 'the foundational cognitive, affective, and evaluative assumptions and frameworks a group of people makes about the nature of reality which the use to order their lives'. Hiebert (2008:26) integreer die werk van Parsons, Shils en Kluckhohn om die interafhanklikheid van die emotiewe, kognitiewe en morele se integrasie te beskryf asook hoe dit gelyktydig funksioneer in die skep van 'n mens se wêreldbeeld. Hiebert (2008:26) sê dat hierdie dimensies gelyktydig afspeel in mense se ervaringswêreld en verduidelik dat mense tergelykertyd dinge kan ervaar, daaroor dink en morele besluite neem wat deur hulle primêre verbintenisse beïnvloed word. Hierdie ervarings, kognitiewe nadenke en morele besluite vind binne ' $n$ bepaalde tyd en ruimte plaas en is voortdurend besig om te verander in ' $n$ wêreld waar daar meer as een normatiewe wêreldbeeld is (Hiebert 2008:26). Die ervaringswêreld en

5.'n Wêreldbeeld sluit in 'n multidimensionele werklikheid wat die totaliteit van die fisiese en transendente dimensies is. Bourne (2008:2) is ook van mening dat ' $n$ wêreldbeeld die diep konneksie is van mense se gedagtes, $n$ tipe kollektiewe wêreldbeeld die diep konneksie is van mense se gedagtes, 'n tipe kollektiewe bewustheid tussen die emosies van mense. Dit sluit ook die konneksie tussen wetenskap en spiritualiteit, intuïsie, kousaliteit en natuurlike etiek in (Bourne
2008:2).

6.Van der Watt (2010) omskryf meerendeels die kognitiewe aspek van die wêreldbeeld, terwyl Hiebert (2008) aandag skenk aan die kousale en dinamiese interaksie tussen die emotiewe en kognitiewe. Albei se aanslag is van belang vir die samestelling vir' $n$ model. 
gedeelde perspektiewe is deel van die dimensies wat die dryfvere van so 'n wêreldbeeld is (Hiebert 2008:26). 'n Wêreldbeeld kan net groei as daar 'n voortdurende interaksie tussen die verskillende komponente plaasvind soos deur Van der Watt (2010) en Hiebert (2008) voorgestel word. Hierdie komponente word ter verduideliking in die volgende afdeling as 'n model geïllustreer.

\section{Integrasie}

In die konstruering van ' $\mathrm{n}$ model word al die aspekte van Van der Watt (2010:14-26) se liniêre model gebruik asook Hiebert (2008:26) se beskrywing van die interaktiewe wisselwerking tussen die kognitiewe, emotiewe en waardeervarings om 'n wêreldbeeld te skep. Skematies word die model as volg voorgestel (sien Figuur 2).

Hierdie model staan bekend as 'n interaktiewe dinamiese model. Die simboliese universum word voorgestel deur 'n groot sirkel wat uit ses sirkels bestaan. Die sirkels word aan mekaar gekoppel deur strepe met pyltjies om die kousaliteit van die proses te illustreer. Die middelste sirkel is die area waar informasie absorbeer word en wat die buitenste sirkels laat 'vibreer'. Die inhoud wat in die sirkels geplaas word, hou dit dinamies. As enige van die sirkels met 'ek'-inhoud gevul word, sal dit selfgerigte uitkomste tot gevolg hê. Wanneer die inhoud van enige van die sirkels met die evangelie gevul word, sal die uitkomste die beginsels van die evangelie wees. In die konteks van die Tessalonisense sou dit beteken dat die wêreldbeeld gevul word met die wêreldbeeld wat Paulus aan die Tessalonisense verkondig het. In die middel van die groot sirkel word die emotiewe en kognitiewe ervarings geplaas. Wanneer 'n individu emosioneel of kognitief reageer, het dit 'n effek op enige van die buite sirkels. Die individu kan byvoorbeeld emosioneel of kognitief reageer op swaarkry wat 'n effek op enige van die sirkels aan

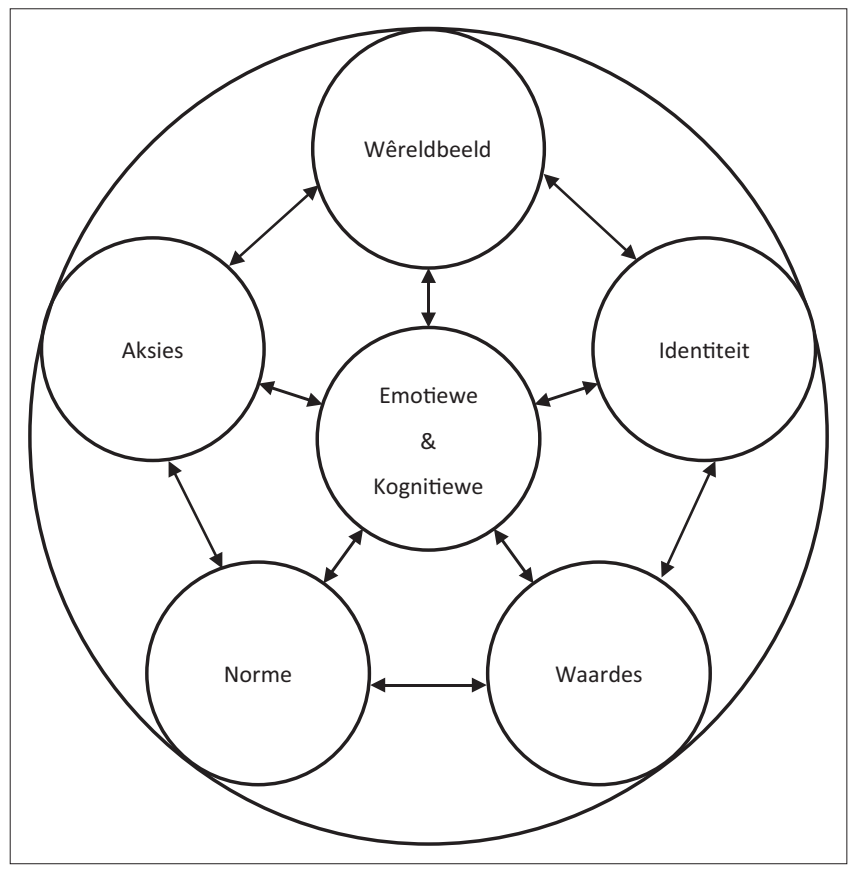

FIGUUR 2: Interaktiewe dinamiese model. die buitekant kan hê. Wanneer hierdie sentrum 'vibreer', veroorsaak dit dat enige van die ander sirkels saam 'vibreer'. Dit beteken dat wanneer iemand byvoorbeeld swaarkry hulle aksies en wêreldbeeld daardeur beïnvloed word. Dit is die area waar mense byvoorbeeld kognitiewe opdragte of emosionele ondersteuning ontvang. Wanneer iemand 'n kognitiewe opdrag ontvang om hulle identiteit te onthou, het dit 'n direkte invloed op die identiteit van die persoon asook op die wêreldbeeld omdat so 'n persoon moet onthou wie hulle in 'n Christengemeenskap is. Wanneer daar van die buitenste sirkels af gewerk word, geld dieselfde beginsels. As iemand ' $n$ waardeprobleem ondervind, word inligting gegee om inhoud aan hulle wêreldbeeld te gee.

Vervolgens word die model verduidelik aan die hand van die ervaring wat die Tessalonisense gehad het toe hulle hulle van die afgode tot die lewende God bekeer het (Tess 1:9).

\section{Toepassing}

Om die model kortliks te illustreer, word daar nou vervolgens na Paulus se verkondiging van sy wêreldbeeld, die Tessalonisense en die impak op hulle emotiewe en kognitiewe verwys. Dit word duidelik aangetoon dat daar 'n skakel is tussen Paulus se verkondiging van die evangelie en die Tessalonisense se bekering (Malherbe 1987:28). Paulus se betrokkenheid in die gemeente begin met evangelisasie as sy persoonlike aksie. Hy skryf aan die gemeente in 1 Tessalonisense 1:5:

want die evangelie wat ons aan julle verkondig het, het nie bloot met woorde tot julle gekom nie, maar ook met krag en deur die Heilige Gees en met volle oortuiging. Julle weet trouens hoe ons by julle opgetree het, en dít om julle ontwil. (volg ook 2:2-4; 2:8; 2:13)

Bekering vir die Tessalonisense word deur Paulus verwoord as die wegdraai van die afgode na die lewende God: 'Die mense vertel self hoe julle ons ontvang het en hoe julle julle van die afgode tot God bekeer het en nou die lewende en ware God dien' (1 Tess 1:9; Malherbe 1987:28). Hierdie aksie van die Tessalonisense het plaasgevind nadat Paulus sy wêreldbeeld aan hulle verkondig het. Daar is 'n verband tussen die wêreldbeeld en die aksie op die model wat vervolgens bespreek sal word.

Die simboliese universum is geaktiveer toe Paulus sy wêreldbeeld aan die Tessalonisense gekommunikeer het. Sy wêreldbeeld is gevul met die evangelie. Regdeur 1 Tessalonisense kom dit duidelik na vore dat Paulus die inhoud van sy wêreldbeeld eksplisiet kommunikeer met verwysing na die drie-enige God. Voorbeelde word gevind in 1 Tessalonisense 1:5 ('krag van die Heilige Gees') en in 3:11-13 as Paulus skryf:

Mag God ons Vader self en ons Here Jesus ons pad na julle toe oopmaak! ${ }^{12}$ En mag die Here julle liefde vir mekaar en vir alle mense laat groei en oorvloedig maak, net soos ons liefde vir julle. ${ }^{13}$ So sal Hy julle innerlik sterk maak dat julle onberispelik en heilig voor God ons Vader sal staan wanneer ons Here Jesus kom saam met al sy heilige engele. Amen. (volg ook, 2:4; 4:3; 4:16-17; 5:19) 
Dit sluit die betrokkenheid van die drie-enige God in sy volheid by die Tessalonisense in. Paulus se wêreldbeeld is gevul met gebed, danksegging, die werking van die Heilige Gees, die terugkeer van Jesus Christus, ensovoorts. Hierdie informasie versterk die nuwe bekeerlinge in hulle geloof en herinner hulle dat hulle na hul bekering 'n nuwe wêreldbeeld aangeneem het.

In 2:1-12 gaan Paulus verder en verdedig die motiewe vir sy persoonlike aksies. Paulus spreek die kognitiewe van die Tessalonisense aan deur hulle daarop te wys hoe hulle die evangelie aangeneem het. Dit impliseer dat die Tessalonisense in hulle wêreldbeeld 'n skuif gemaak het weg van die afgode na die lewende God toe. Die inhoud van die evangelie het die Tessalonisense kognitief 'getref' en hulle het daarop reageer (Tess 1:5-8; 2:13). Daar het 'n nuwe lewe vir die bekeerlinge aangebreek met nuwe uitdagings waarop hulle nie noodwendig emosioneel of kognitief voorberei was nie. Daarom tref Paulus onderskeid tussen die lewende God en die afgode (Tess 1:9). Die wêreldbeeld wat Paulus verkondig het, impliseer dat hulle status verander na dié wat deur God gekies is (Tess 1:4). Nadat hulle wêreldbeeld verander het, het hulle die aanbidding van afgode verwerp (Ciampa \& Rosner 2010:17). Die aanvaarding van 'n nuwe wêreldbeeld het 'n liniêre proses aan die gang gesit wat hulle identiteit, waardes, norme en aksies beïnvloed het.

Hierdie verandering het nie sonder 'n prys plaasgevind nie. Enige verandering het kognitiewe en emosionele implikasies. Hulle families het hulle verkwalik omdat hulle nie meer afgodsfeeste bygewoon het nie en hulle kon nou as 'n sekte bekend gestaan het (Barclay 1993:515). Dit het emosionele spanning vir hulle meegebring wat swaarkry tot gevolg gehad het. De Villiers (2005:310) stem saam dat hulle bekering baie aandag sou trek, veral in die sosiale konteks waarin hulle hulleself bevind het. Hulle het volgens Paulus die evangelie in baie swaarkry aangeneem, maar ook met blydskap in die Heilige Gees (Malherbe 1987:46). Malherbe (1998:232-235) en Witherington (2006:72) dui aan dat die nuwe bekeerlinge op kognitiewe en emotiewe vlak gedisoriënteer was. Ons sien dat Paulus hulle swaarkry wat op verskillende vlakke gelê het, koppel aan 'n wêreldbeeld waar God hulle krag gee deur die Heilige Gees (Tess 1:6). Paulus is bekommerd oor hulle emotiewe en kognitiewe toestand en doen moeite om die nuwe gemeente in stand te hou en op te bou deur byvoorbeeld vir Timoteus te stuur om te gaan kyk hoe dit met hulle gaan:

Ons het vir Timoteus, ons broer en medewerker in diens van God, wat saam met ons die evangelie van Christus verkondig, na julle toe gestuur om julle in julle geloof te versterk en moed in te praat ${ }^{3}$ sodat nie een van julle onder die vervolginge sou begin wankel nie. Dat ons ter wille van ons geloof vervolg sal word, staan vas. Dit weet julle. (1 Tess 3:2)

Paulus het verder ook die brief geskryf om hulle aan te spoor om mekaar te bemoedig (Malherbe 1987:61). Paulus verruim hulle wêreldbeeld deur hulle daarop te wys dat swaarkry 'n gegewe vir volgelinge van Jesus is (Tess 3:3). 'n Verdere kognitiewe uitdaging vir die Tessalonisense was dat daar twyfel ontstaan het oor wat met hulle geliefdes gebeur wat doodgaan (Tess 4:13-18), veral omdat hulle dalk nog kon glo dat afgode hulle met die dood straf (Barclay 1993:515). Malina en Pilch (2006:33) sê dat Paulus in Tessalonisense 4:13-18 die gemeente aanmoedig om vir mekaar om te gee en te troos oor die verlies wat hulle ervaar. Hierdie teksgedeelte word aan die emotiewe sirkel gekoppel wat die buitenste sirkels laat vibreer. Dit verklaar waarom Paulus soveel belangstelling toon in die nuwe bekeerlinge se sielkundige gesteldheid en hulle sosiale verhoudings (Malherbe 1987:46).

Daar word van hulle verwag om onberispelik voor God te leef. Paulus behandel die saak van losbandigheid, eerlikheid, broederliefde, eie handewerk en welvoeglike lewenswandel. Paulus skryf aan die gemeente in 1 Tessalonisense 4:

Dit is die wil van God dat julle heilig moet lewe. Weerhou julle van onsedelikheid. ${ }^{4}$ Elkeen van julle moet weet dat hy met sy vrou heilig en eerbaar moet saamlewe; ${ }^{5}$ julle moenie deur hartstog en begeerte gedrywe word soos die heidene wat vir God nie ken nie. ${ }^{6}$ Ook mag niemand hom in hierdie verband te buite gaan en sy broer bedrieg nie, want die Here straf al sulke dinge. So het ons julle trouens al vroeër gewaarsku; ons het julle nadruklik hierop gewys. ${ }^{7}$ God het ons nie geroep om onsedelik te lewe nie, maar om heilig te lewe. (v. 3-7)

Paulus wil hiermee normes en waardes in die gemeente se midde vestig. Die bekeerlinge word weer in Tessalonisense 5:3-8 herinner aan die norm dat hulle in die lig moet leef, want daar is belangrike waardes wat in stand gehou moet word soos byvoorbeeld om nie dronk te word nie.

Dit is duidelik dat Paulus op verskillende aspekte van die Tessalonisense fokus om hulle pastoraal te bedien nadat hulle tot bekering gekom het. Paulus vul die gemeente se wêreldbeeld met die evangelie wat 'n effek op hulle aksies, norme, waardes, identiteit, emosionele en kognitiewe het. Dit gee hulle'n nuwe verwagting op die koms van die Here Jesus.

\section{Gevolgtrekking}

In hierdie artikel is 'n model ontwikkel wat as lens kan dien vir die lees van Paulus se briewe. 1 Tessalonisense is as toetsgeval gebruik. Paulus verkondig die evangelie aan die Tessalonisense en daag hulle uit om 'n nuwe wêreldbeeld te aanvaar. Dit is duidelik dat wanneer die Tessalonisense 'n nuwe wêreldbeeld aanvaar en nuwe inhoud aan hulle lewe gee, hulle totale lewe verander. Die voorgestelde model werp lig op die proses wat Paulus gebruik om sy wêreldbeeld aan die Tessalonisense te kommunikeer asook watter dinamiek geaktiveer word nadat die Tessalonisense Paulus se wêreldbeeld aanvaar het. Dit is duidelik dat daar 'n verband is tussen die wêreldbeeld van die Tessalonisense en hulle aksies. ' $n$ Keuse is gemaak vir 'n pastoraal hermeneutiese lees van 1 Tessalonisense as toetsgeval. Die moontlikhede om die model aan te wend vir ' $n$ pastorale hermeneutiese lees van Paulus se briewe kan verder ondersoek word. 


\section{Erkenning \\ Mededingende belange}

Die outeur verklaar dat hy geen finansiële of persoonlike verbintenis het met enige party wat hom nadelig kon beïnloed het in die skryf van hierdie artikel nie.

\section{Literatuurverwysings}

Aagaard-Hansen, J., 2007, 'The challenges of cross-disciplinary research, social epistemology', A Journal of Knowledge: Culture and Policy 21(4), 425-438. http:// dx.doi.org/10.1080/02691720701746540

Barclay, J.M.G., 1993, 'The conflict in Thessalonica', Catholic Biblical Quarterly 55(3), 512-530.

Baumann, E.K., 2011, Worldview as worship, the dynamics of a transformative Christian education, Wipf \& Stock Publishers, Eugene, OR.

Berger, P.L. \& Luckmann, T., 1966, The social construction of reality: A treatise in the sociology of knowledge, Doubleday \& Company, New York, NY.

Bourne, E.J., 2008, Global shift. How worldview is transforming humanity, New Harbinger Publications Inc., Oakland, CA.

Bowald, M.A., 2007, 'Rendering mute the word: Overcoming deistic tendencies in modern hermeneutics; Kevin Vanhoozer as a test case', Westminister Theological Journal 69(2), 367-381.

Brown, R.H., 1987, Society as text, essays on rhetoric, reason and reality, The University of Chicago Press, Chicago, IL.

Charon, J.M., 2004, Symbolic interactionism, an introduction, an interpretation, an integration, 8th edn., Pearson Prentice Hall, Upper Saddle River, NJ.

Ciampa, R.E. \& Rosner, B.S., 2010, The first letter to the Conrinthians, pillar New Testament commentary, Wm. B. Eerdmans Publishing Co., Grand Rapids, MI.

De Villiers, P.G.R., 2005, 'Safe in the family of God: Soteriological perspectives in 1 Thessalonians', in J.G. van der Watt (ed.), Salvation in the New Testament: Perspectives on soteriology, pp. 305-330, Brill, Leiden.

Engberg-Pedersen, T., 2000, Paul and the stoics, T\&T Clark Ltd., Edinburgh.

Freedman, J. \& Combs, G., 1996, Narrative therapy, the social construction of preferred realities, W.W. Norton \& Co., New York, NY.

Hays, R.B., 2006, 'Mapping the field: Approaches to New Testament ethics', in J.G. van der Watt (ed.), Identity, ethics, and ethos in the New Testament, pp. 3-19, Walte Gruyter, Berlin.

Hiebert, P.G., 2008, Transforming worldviews, an anthropological understanding of how people change, Baker Academic, Grand Rapids, MI.

Horrel, D., 1993, 'Converging ideologies: Berger and Luckmann and the Pastoral Epistles', Journal for the Study of the New Testament 15(50), 85-103. http://dx. doi.org/10.1177/0142064X9301505006

Kahan, D., 2010, 'Bystander theology and the desire to end a hermeneutic hegemony', Biblical Theology Bulletin 40(3), 138-147. http://dx.doi.org/10.1177/ 0146107910375548
Lategan, B., 2009a, 'New Testament hermeneutics (part I): Defining moments in the development of biblical hermeneutics', in A. du Toit (ed.), Focusing on the message, New Testament hermeneutics, exegesis and methods, pp. 13-63, Protea message, New Testam
Book House, Pretoria.

Lategan, B., 2009b, 'New Testament hermeneutics (part II): Mapping the hermeneutical process', in A. du Toit (ed.), Focusing on the message, New Testament hermeneutics, exegesis and methods, pp. 65-105, Protea Book House, Pretoria.

Luckensmeyer, D., 2009, The eschatology of first Thessalonians, Vandenhoeck \& Ruprecht, Göttingten.

Malherbe, A.J., 1977, Social aspects of early Christianity, Louisiana State Press, Baton Rouge, LA.

Malherbe, A.J., 1987, Paul and the Thessalonians, Fortress Press, Minneapolis, MN.

Malherbe, A.J., 1989, Paul and the popular philosophers, Fortress Press, Minneapolis, $\mathrm{MN}$.

Malherbe, A.J., 1998, 'Conversion to Paul's Gospel', in A.J. Malherbe, F.W. Norris \& J.W. Thompson (eds.), The early Church in its context, essays in honor of Everett Ferguson, pp. 230-244, Brill, Leiden.

Malherbe, A.J., 2000, The letters to the Thessalonians, a new translation with introduction and commentary, Doubleday, New York. (The Anchor Bible, 32B).

Malina, B.J. \& Pilch, J.J., 2006, Social-science commentary on the letters of Paul, Fortress Press, Minneapolis, MN.

Neyrey, J.H., 2008, 'Preface', in J.H. Neyrey \& E.C. Steward (eds.), The social world of the New Testament, insights and models, pp. xxi-xxiv, Hendrickson Publishers, Peabody, MA.

Osmer, R.R., 2012, 'Toward a new story of practical theology', International Journal of Practical Theology 16(1), 66-78. http://dx.doi.org/10.1515/ijpt-2012-0006

Rubin, H.J. \& Rubin, I.S., 1995, Qualitative interviewing, the art of hearing data, Sage Publications, Inc., Thousand Oaks, CA.

Runia, K., 1984, 'Hermeneutics of the reformers', Calvin Theological Journal 2, 121-152.

Stamoolis, J., 2004, 'Scripture and hermeneutics: Reflections over 30 years', Evangelical Review of Theology 28(4), 337-344.

Thiselton, A.C., 2009, Hermeneutics: An introduction, Wm. B. Eerdmans Publishing Co., Grand Rapids, MI.

Thiselton, A.C., 2011, 1 \& 2 Thessalonians, through the centuries, John Wiley \& Sons Ltd., Chichester. (Blackwell Bible Commentaries).

Thompson, J.W., 2006, Pastoral ministry according to Paul: A biblical vision, Baker Academic, Grand Rapids, MI.

Van der Watt, J.G., 2010, 'Thou Shalt ... do the will of God'. Do New Testament ethics have anything to say today? Van Eck \& Oostrinck, Nijmegen.

Walsh, B.J. \& Middleton, J.R., 1984, The transforming vision, shaping a Christian world view, InterVarsity Press, Downers Grove, IL.

Wanamaker, C.A., 2000, 'Epistolary vs. rhetorical analysis: Is a synthesis possible?', in K.P. Donfried \& J. Beutler (eds.), The Thessalonians debate, methodological discord or methodological synthesis?, pp. 255-286, Wm. B. Eerdmans Publishing discord or methodological
Co., Grand Rapids, MI.

Witherington, B., 2006, 1 and 2 Thessalonians, a socio-rhetorical commentary, Wm. B. Eerdmans, Grand Rapids, MI. 